\title{
SOUTHERN COUNTRIES OF THE EUROPEAN UNION IN A DEBT TRAP: WHAT OPTIONS ARE ON THE TABLE?
}

\section{MILAN BEDNÁR̆}

\begin{abstract}
:
This paper analyses the current debt situation of five Southern countries of the eurozone - Spain, France, Greece, Italy, and Portugal. By using values of key debt variables between 1996 and 2016, we show that all the countries, except Italy, are caught in a debt trap. Moreover, Greece and Portugal cannot solely rely on fiscal austerity because they would need to achieve unreasonably high budgetary surpluses in a period longer than 30 years to reduce the excessive debts. Moderate results were shown in the case of France and Spain. Nevertheless, the latter country is suffering from high real interest rates on the government debt which are currently higher than $10 \%$. Moreover, we identified and analysed four main possibilities of dealing with the debts: debt monetization, fiscal consolidation, structural reforms, and sovereign default. The debt monetization as practised by the ECB is not an appropriate solution, its secondary effects are making the situation worse, while its primary effects are based on a short-term perspective. Appropriate fiscal consolidation seems to be based on cutting expenditures. However, the target is not achievable without structural reforms. Some authors claim, that the reforms should be mainly demand-driven, however, we show that this is not the case. Based on historical evidence, the GDP growth does not serve as the main factor of reducing indebtedness. In fact, it was significant in less than $40 \%$ of the time in the examined period. Finally, we claim that due to the political motivations, there is a lack of emphasis on real competitive advantages. A return to market principles in many cases is needed, which is in contrast with the usual growth-driven reforms. When there is an insufficient political will to carry out reforms, a proper and fully-executed sovereign default would accelerate functioning of correction mechanisms in the EMU/EU. Unfortunately, such action was not executed in the case of Greece, even though the country has de-facto bankrupted.
\end{abstract}

\section{Keywords:}

European Union, eurozone, indebtedness, debt trap, economic policy

JEL Classification: E60, F30, H60

\section{Authors:}

MILAN BEDNÁŘ, Faculty of Economics, University of Economics in Prague, Czech Republic, Email: milan.bednar@vse.cz

\section{Citation:}

MILAN BEDNÁŘ (2018). Southern Countries of the European Union in a Debt Trap: What Options Are on the Table?. International Journal of Economic Sciences, Vol. VII(2), pp. 1-34.,

10.20472/ES.2018.7.2.001 
Acknowledgements: The author would like to thank to the two anonymous reviewers of the International Journal of Economic Sciences for their comments which helped to enhance this article. 


\section{Introduction}

It seems that the sovereign debt crisis in the eurozone has ended, however, the opposite is true. Southern countries of the European Union accumulated high debts and future prospects are uncertain. Economists usually prefer to give their recommendations based on a political climate, concerning short-term solutions, rather than trying to establish sustainable policies. In addition, the problem needs to be examined using different perspectives and taking account all the possible secondary effect and putting the empirical literature together. Some authors claim that the Southern countries are in specific situation, hence, the solutions should be also specific. Regan (2017) states that the Southern EU countries rely on different macroeconomic aregime which is more demand-driven. This article aims to tackle such claims by analysing the problem from different angles. We specifically aim to present evidence whether the typical demand-driven (or growthdriven) approaches are suitable, given the circumstances, or not.

The analysis in the paper has two main objectives. First, we present a debt sustainability analysis and evaluate a hypothesis that all of the examined countries are currently caught in a debt trap, i.e. their debt situation is unsustainable. The second objective is to analyse possible solutions to the issue, e.g. demand-led revival. We are examining midterm and long-term outlooks and resolutions.

The paper briefly mentions research made on the relationship between debt and growth. Then, we examine the current situation and possible prospects of five Southern eurozone countries: Spain, France, Greece, Italy, and Portugal, by employing an investigation of their debt dynamics. In the last section, we present and discuss solutions to the excessive indebtedness.

We use both theoretical analysis and empirical analysis. The used data come from the Eurostat, OECD, and CRAG database. The conclusions are confronted with a wide range of research made by various authors. Moreover, we are examining the period between 1996 and 2016. This 
has two reasons. First, it is selected due to data availability. Second, we need to analyse a recent history because these parameters are rapidly becoming obsolete.

\section{Relationship between debt and growth}

From the theoretical perspective, we can distinguish between three main approaches. Neoclassical branch finds macroeconomic impacts of budget deficit to be negative. Keynesian approach finds the impact positive, however, only in some cases. Finally, Neo-Ricardianism states that there is no impact (Strecha, 2015, p. 330). The evidence and beliefs about the Ricardian equivalence are mixed. Moreover, despite its brilliance, the concept does not have strong theoretical background, especially when considering new insights of behavioural economics made in the recent decades. David Ricardo himself did not believe that the theorem holds, he rather supported debt-illusion explanation (Brennan, 2012, p. 186). Stanley (1998) in his meta-study concluded that there is no evidence of the equivalence. Therefore, the debate is whether there exist some special circumstances as suggested by the Keynesian approach. Authors who are in favour of indebtedness usually mention its long-term growth effects when making appropriate investments, and in times of crises, depressed economies may need a "push". Unfortunately, there is an evidence that due to the political process, profitable investments are rarely made, the resources are usually wasted on supporting political campaigns. The second reason is not valid either because of its unsustainability. By postponing a recession, the negative long-term effects are becoming only worse. The eurozone and its design is a clear example of unsoundness of the attitude. Theory also suggests problems of the political process. Hishow (2011, p. 330) explained the rationality of policymakers' fear from fiscal discipline as they are likely to be punished by voters who lost their jobs in the wake of budget reforms. This was strengthened by the design of the eurozone when socialisation of risk and losses is possible. 
Baboš and Gál (2014) summarised results of 9 comprehensive empirical studies from 2010-2013 concerning impacts of high debt and recommended to new EU member states to avoid high debt levels due to its negative influence on GDP growth and problems connected with deleveraging. All mentioned papers present negative growth effects of high debt to GDP ratio (usually between $85 \%$ and $100 \%$ ), with only one exception, Herndon, Ash, and Pollin (2013), to be specific. These authors criticised the well-known work of Rogoff and Reinhart (2010) arguing that the negative effect is not present in every case of high debt. Égert (2015) also mentioned lapses in the original study of Rogoff and Reinhart, however, his results also suggest the negative impact of high debt which is kicking in at already moderate public debt levels in some cases. A newer study of Woo and Kumar (2015) confirms the hypothesis as well. Authors found that there is a slowdown in labour productivity growth mainly due to reduced investment and slower growth of capital per worker. In addition, state of high debt may not only increase uncertainty in an economy but also raise its vulnerability to crises, leading to greater macroeconomic volatility (ibid., p. 729). It is possible that it does not matter whether these empirical studies really uncovered the real relationship. Even if there is no definite statistical proof, history indicates that episodes of high debt growth in the EU were not successful in the mid-term or the long-term because the resources were usually spent rather ineffectively. According to the economic theory, and the empirical studies, negative effects of high debt on GDP growth (a whole economy) are indisputable. Furthermore, indebtedness is a burden on the shoulder of future generations.

Finally, we argue that there is no need to completely get rid of the debt by cause of the costs being prohibitive. As mentioned earlier, comprehensive studies found the relevant threshold ${ }^{1}$ of debt to GDP ratio to be between $85 \%$ to $100 \%$. It would probably be sufficient for the Southern EU countries to comply with the Maastricht criterion of $60 \%$ for two reasons. First, it provides a sufficient buffer when an economy

\footnotetext{
${ }^{1}$ It refers to a level of indebtedness when GDP growth is being significantly constrained.
} 
is having problems. Second, these countries formally pledged to follow the rule. A reversing of the trend is the first step. As stated by Hishow (2011, p. 327): "Reversing the destructive trend of high indebtedness is a good idea given that Europe's debt ratio has never stopped growing during the last couple of decades".

\section{Debt sustainability analysis}

According to the IMF's World Economic Outlook (April 2017 edition), the top 10 most indebted countries include Japan, three examined Southern European states (Greece, Italy, Portugal), and six mostly developing states. The last two analysed countries (Spain and France) occupy places near $20^{\text {th }}$ position worldwide. All the Southern countries have either already reached a $100 \%$ ratio of gross debt to GDP or are very close to it. Mentioned states most likely exhibit negative effects of the accumulated debt ${ }^{2}$. When we consider the world placement, it is safe to assert that we are looking at extreme values of indebtedness.

While some level of debt is acceptable, this is not the case. Gros (2012, p. 37) argues that the problem is even worse considering that in the core of it is a classic maturity mismatch. A government has mostly long-term assets, while its liabilities are of a much shorter duration. The shorter is an average maturity of debt, the more frequently a government has to refinance the debt ${ }^{3}$. According to the European Central Bank, the average residual maturities of general government debt in 2016 were: Greece (16.6 years), France (8 years), Italy (7.3 years), Spain (7 years), Portugal (6.3 years) 4 . In addition, Gros (ibid.) compares this situation to a bank run, where a central bank is the lender of last resort. However, in case of the eurozone, there is no independent national central bank.

\footnotetext{
${ }^{2}$ According to the empirical research mentioned in the previous chapter.

${ }^{3}$ If a debt maturity is 8 years and the debt is worth $100 \%$ of GDP, the country has to refinance $12.5 \%$ of it each year. It is way more than any country can afford to repay.

4 As it is shown in the table no. 3 below, even the maturity of Greece's debt is not safe in the long-term.
} 
Prior to our deeper analysis, a definition of used variables and equations is needed. We employ basic equations concerning forming of government debt as mentioned by Escolano (2010). Let $d_{t}$ denote overall debt to GDP ratio at time $t, p_{t}$ is primary balance to GDP ratio at time $t$, and $b_{t}$ represents budget balance to GDP ratio at time $t$. In addition, ipt represents interest payments on the debt stock outstanding at the end of $t-1$ to GDP ratio at time $t, r$ stands for real interest rate paid in period $t$ on the debt stock outstanding at the end of $t-1$, and $g$ is real GDP growth between $t-1$ and $t$. Next, we introduce a coefficient measuring risk of a debt trap, which is defined as follows:

$$
\lambda_{t}=\frac{r-g}{1+g}
$$

Notice that:

$$
1+\lambda_{t}=\frac{1+r}{1+g}
$$

In other words, it represents a change due to the difference in real interest rate and GDP growth. When the real interest rate is greater than growth, the country is facing problems, and in order to keep the same level of debt, it needs to run budget surpluses. It is shown below. The equation no. 3 serves as a basic formula of debt dynamics:

$$
d_{t}=\left(1+\lambda_{t}\right) d_{t-1}-p_{t}
$$

Furthermore, the relationship between the primary balance and the budget balance is as follows:

$$
p_{t}=b_{t}+i p_{t}
$$

Moreover, the next equation deals with a primary balance which is needed to stabilise debt to GDP ratio in a given year: 


$$
p_{t}^{*}=\lambda_{t} d_{t}^{*}
$$

Finally, a decomposition of effects of the real interest rate, the real GDP growth, and the primary balance on debt to GDP ratio can be obtained from the equation no. 1 and no. 3 .

$$
d_{t}-d_{t-1}=\frac{r_{t}}{1+g_{t}} d_{t-1}-\frac{g_{t}}{1+g_{t}} d_{t-1}-p_{t}
$$

We begin our analysis examining the coefficient regarding the risk of a debt trap $(\lambda)$. For a clearer understanding of the impacts of $\lambda$ on debt dynamics, we can assume that it serves as a percentage change of a debt ratio $d_{t}$. The higher is the value, the worse it is for the economy 5 . Table no. 1 contains historical averages of these coefficients for the Southern states of the EU.

\begin{tabular}{|c|c|c|c|c|c|c|}
\hline Country & $\begin{array}{l}\text { Full } \\
\text { period } \\
(1996- \\
2016)\end{array}$ & $\begin{array}{l}\text { Actual } \\
\text { year } \\
(2016)\end{array}$ & $\begin{array}{c}\text { First } \\
\text { decade } \\
(1996- \\
2005)\end{array}$ & $\begin{array}{c}\text { Second } \\
\text { decade } \\
(2006- \\
2015)\end{array}$ & $\begin{array}{l}\text { Crisis } \\
\text { period } \\
(2007- \\
2010)\end{array}$ & $\begin{array}{c}\text { After- } \\
\text { crisis } \\
\text { period } \\
(2011- \\
2016)\end{array}$ \\
\hline Spain & 2.15 & -2.31 & -4.99 & 9.96 & 12.19 & 9.76 \\
\hline France & 1.87 & -0.79 & 3.43 & 0.54 & 3.89 & -1.66 \\
\hline Greece & 2.84 & 1.77 & -1.35 & 7.30 & 10.13 & 6.96 \\
\hline Italy & 1.29 & 0.94 & -0.35 & 2.99 & 4.34 & 2.20 \\
\hline Portugal & 5.00 & 2.90 & 2.83 & 7.41 & 8.56 & 6.23 \\
\hline
\end{tabular}

Table no. 1 - Debt trap risk coefficients (averages, in \%)

Source: Eurostat, own calculations and processing.

Note: The real interest rate was calculated on the basis of the equation no. 6 .

Not a single examined country exhibited a negative average coefficient between 1996-2016 which means that average real interest rate was

\footnotetext{
${ }^{5}$ Positive values imply that government needs to run budget surpluses in order to counter the negative effect of real interest rate on debt (GDP growth by itself is insufficient).
} 
greater than average GDP growth, increasing the debt. Surprisingly, Portugal with the coefficient of $5 \%$ was in the most alarming situation. The countries were in the most favourable spot in the first decade (1996-2015). Averages of the second decade got much worse mostly due to the global financial crisis and subsequent European sovereign debt crisis. These years are shown separately, all the countries exhibited the worst risk coefficients back then. Unfortunately, the postcrisisyears averages are still distressing. Spain, Greece, and Portugal are experiencing very high rates of the coefficients. Only France made a considerable progress by having the coefficient negative, nevertheless, it can be quite volatile.

Table no. 2 - Differences between actual primary balances and debt stabilising primary balances (averages, \% of GDP)

\begin{tabular}{|c|c|c|c|c|c|c|}
\hline Country & $\begin{array}{c}\text { Full } \\
\text { period } \\
(1996- \\
2016)\end{array}$ & $\begin{array}{c}\text { Actual } \\
\text { year } \\
(2016)\end{array}$ & $\begin{array}{c}\text { First } \\
\text { decade } \\
(1996- \\
2005)\end{array}$ & $\begin{array}{c}\text { Second } \\
\text { decade } \\
(2006- \\
2015)\end{array}$ & $\begin{array}{l}\text { Crisis } \\
\text { period } \\
(2007- \\
2010)\end{array}$ & $\begin{array}{l}\text { After- } \\
\text { crisis } \\
\text { period } \\
\text { (2011- } \\
\text { 2016) }\end{array}$ \\
\hline Spain & -3.09 & 6.20 & 3.02 & -10.98 & -11.47 & -11.28 \\
\hline France & -2.29 & -0.94 & -0.39 & -3.94 & -6.90 & -2.52 \\
\hline Greece & -4.50 & -4.71 & 1.55 & -12.55 & -14.66 & -14.05 \\
\hline Italy & 0.85 & 0.35 & 3.66 & -2.11 & -3.49 & -1.18 \\
\hline Portugal & -5.58 & -1.58 & -2.77 & -9.80 & -10.82 & -8.47 \\
\hline
\end{tabular}

Source: Eurostat, own calculations and processing.

Note: The real interest rates were calculated on the basis of the equation no. 6 . 
Table no. 3 - Real interest rates on outstanding government debt (averages, in \%)

\begin{tabular}{|c|c|c|c|c|c|c|}
\hline Country & $\begin{array}{c}\begin{array}{c}\text { Full } \\
\text { period }\end{array} \\
(1996- \\
2016)\end{array}$ & $\begin{array}{c}\text { Actual } \\
\text { year } \\
(2016)\end{array}$ & $\begin{array}{c}\text { First } \\
\text { decade } \\
(1996- \\
2005)\end{array}$ & $\begin{array}{c}\text { Second } \\
\text { decade } \\
(2006- \\
2015)\end{array}$ & $\begin{array}{l}\text { Crisis } \\
\text { period } \\
(2007- \\
2010)\end{array}$ & $\begin{array}{l}\text { After- } \\
\text { crisis } \\
\text { period } \\
(2011- \\
2016)\end{array}$ \\
\hline Spain & 4.32 & 0.85 & -1.43 & 10.41 & 12.52 & 10.12 \\
\hline France & 3.45 & 0.41 & 5.79 & 1.41 & 4.27 & -0.68 \\
\hline Greece & 3.58 & 1.78 & 2.36 & 4.97 & 8.18 & 3.40 \\
\hline Italy & 1.81 & 1.83 & 1.11 & 2.50 & 3.42 & 1.82 \\
\hline Portugal & 6.21 & 4.37 & 5.36 & 7.24 & 8.97 & 5.66 \\
\hline
\end{tabular}

Source: Eurostat, own calculations and processing.

Note: The real interest rates were calculated on the basis of the equation no. 6 .

Table no. 2 illustrates the character of primary balances achieved by the governments of these countries between 1996 and 2016, while table no. 3 shows data on real interest rates paid by these countries. On average in the whole period, governments ran budget balances that were increasing indebtedness of these states, excluding Italy. This country as shown in the table is managing its government debt rather responsibly. Despite the economic recovery after the 2008-9 recession, Greece, Spain, and Portugal are still showing detrimental primary balances when compared to primary balances needed to stabilise the debt. Even France and Italy are not stabilising.

In the last part of the analysis, we present debt projections. We take into account standard budgetary balances as well as primary balances in relation to GDP which are needed to achieve the goal of reducing the 
debt ratio to the Maastricht criterion level. Italy's situation is confirmed to be sustainable, while Greece and Portugal cannot solely rely on fiscal austerity. Moderate results were showed in the case of France and Spain.

Table no. 4 - Projections of target variables and years to reach $60 \%$ debt to GDP ratio,2017 and beyond (in \%)

\begin{tabular}{l|ccc}
\multicolumn{2}{c}{$\begin{array}{c}\text { Primary balance } \\
\text { to GDP }\end{array}$} & $\begin{array}{c}\text { Budget balance } \\
\text { to GDP }\end{array}$ & Years needed \\
\hline Italy & 5.0 & -0.5 & 20 \\
France & 5.0 & 2.3 & 11 \\
Spain & 5.0 & 2.2 & 13 \\
Greece & 7.5 & 1.8 & 32 \\
Portugal & 7.5 & 4.0 & 32
\end{tabular}

Source: Eurostat, own calculations and processing.

Notes: The data were calculated on the basis of the equations no. 3, 4, and 5. The calculations are based on historical averages of used variables between 19962016.

Moreover, we need to explore which of the main variables is the most impactful one when it comes to indebtedness. We decomposed historical effects of the real interest rates, real GDP growths, and primary balances on government debt by using the equation no. 6 (see the appendix). The most impactful variable was the real interest rate. On average, its effect contributed $52-68 \%$ to corresponding changes in the countries' indebtedness. 
It is obvious that Portugal, Greece, Spain, and France are in a debt trap if nothing significant happens and the values are close to its historical averages. For instance, structural reforms boosting economic growth or sharp incline toward budgetary responsibility would help. Portugal's position is same or even a bit worse than Greece's when we take into account the high real interest rateshown in table no. $3,{ }^{6}$ the situation looks alarming. However, we need to mention the position of Italy, which is characterised by high but rather sustainable debt. In the future, we should not expect miracles, these countries may lose portions of their competitive advantages as other today's emerging countries will flourish. In addition, Cecchetti, Mohanty, and Zampolli (2010) claim that drastic measures will be needed to counter negative circumstances of raising costs such as population ageing.

\section{Possibilities of dealing with the excessive indebtedness}

The goal of this section is to provide an overview of usable options and analyse the situation the states are in. There are three ways of how to fund a budget deficit: debt financing (domestic or external debt), money financed deficit (debt monetization), and sale of assets (Strecha, 2015, p. 332). We should bear in mind that these options can also be useful when trying to reduce indebtedness. A temporary increase in debt can help if effective investments are made. A debt monetization can help finance the debt, as well as a sale of assets. Other, more general ways of reducing relative indebtedness include a change in fiscal policy stance (fiscal consolidation - increasing revenues or decreasing expenditures), a sovereign default, or a reliance on GDP growth. By grouping some options together, we see four main possibilities: debt monetization, fiscal consolidation, structural reforms (or boosting GDP growth), and default (or unilateral debt write-off).

\footnotetext{
${ }^{6}$ Greece's real interest rate is smaller, possibly due to agreements that have been made. In addition, their debt has been bailed-out, to some extent. One may argue that Greece has already bankrupted.
} 


\subsection{Debt monetization in the EMU}

A monetization can help reduce indebtedness by two ways. First, if a bailout takes place, the government debt is repaid by other subjects. Second, inflationary pressures reduce a real debt value. Nevertheless, the issue is more complicated when it is being carried out in a monetary union.

Problems in Europe starting during the first half of the 1990s strengthened the drive for Economic and Monetary Union (EMU). Back then, it was argued, for Spain and Italy, that the only way out of the inflation and continuous depreciation is joining the EMU. Nevertheless, the euro crisis leads to exactly opposite conclusions (Gros, 2012, p. 36).

Gros (ibid.) adds: "It is now argued that financing a high public debt in a monetary union is particularly difficult, or at least unstable because a government that loses the confidence of investors has no other option left than to default." In addition, a monetary union is usually undergoing some phases, and once the EMU's initial phase with its low-interest levels and high growth rates expire, it will become even more difficult to reduce the indebtedness of the countries (Baumgarten \& Klodt, 2010, p. 375). The problems of the eurozone's design related to debt dynamics are well-known. We mean mostly asymmetric effects of some uniform variables. Sinn (2018) is talking about interest rate and exchange rate blockage, comparing the situation to the case of Dutch disease, which is hampering the competitiveness of the Southern countries. In addition, it may be useful to mention the current state of internal imbalances within the EMU as an indicator of its situation.

Although the current accounts of the southern countries are currently more balanced, ${ }^{7}$ there are still imbalances in the Target2 system. Moreover, these imbalances got even higher than their peak levels

\footnotetext{
${ }^{7}$ Greece achieved in 2015 a slightly positive current account balance of $0.1 \%$, according to the Eurostat.

Other examined countries are running notable surpluses.
} 
around the year $2012^{8}$ and they amount to high shares of GDP in case of selected countries ${ }^{9}$ - Portugal $(41.80 \%)$, Greece (40.48\%), Spain $(34.40 \%)$, Italy $(23.78 \%)$. France's imbalances are negligible. Dutch Central Bank (De Nederlandsche Bank 2016) states that these imbalances were triggered by a loss of confidence in banks in the past (demand-driven) but currently they are rather a result of the quantitative easing made by the European Central Bank (supply-driven) ${ }^{10}$. Nevertheless, if the monetary union functioned well, there would be no significant imbalances as the created liquidity would be absorbed by the countries' banking systems more evenly.

It should be added, that membership in the EMU implies that ECB needs to make a final decision about debt monetization, not individual countries. Lucarelli (2014, p. 216) claims that national governments need to rely more on financial markets in the formulation of national policy, which is suboptimal. In other words, the European Central Bank is in a desperate position due to the faults of the EMU. The current status shows the risk perceptions and fragmentation of the EMU did not disappear (De Nederlandsche Bank 2016). Therefore, the risk of another EMU's bailout is still in play (it is very likely to happen to some extent). A bailout would be a regretful one-shot solution, especially if no significant changes are made. To some extent, we may observe it in the case of Greece.

While the quantitative easing did not exhibit significant inflationary pressures for now, it does not mean the future will be the same - a change of externals factors may occur. Inflationary pressures could absorb another portion of the debt; however, it affects a whole economy, it is creating instabilities, uncertainty, and there is no

\footnotetext{
${ }^{8}$ It should be noted that the imbalances may reflect public as well as private debts.

${ }^{9}$ We are using 2016 GDP values from the Eurostat, and July 2017 data on imbalances from the European Central Bank.

${ }^{10}$ They believe that many of the institutional investors that are selling financial instruments under the QE regime prefer to hold deposits at banks with the highest perceived creditworthiness.
} 
particular reason why debtors should benefit this way at the expense of creditors $^{11}$. Moreover, some of the effects are hidden. Many states' housing markets are booming, and both prices and yields of government bonds are affected. While the latter means easier management of debt, it is possibly causing relative losses of subjects which are holding these instruments as other investments, which could be way more beneficial in the long-term, were not made due to the market distortions. Furthermore, governments issuing the instruments experience no relevant feedback which would arise from their expansionary policies. The current expansionary strategies of many central banks undoubtedly helped in the short-term, most notably during the crisis. However, it is a fatal mistake to continue the trend because it will make the situation even worse. The quantitative easing does not solve the structural issues of low inflation and low GDP growth but rather the opposite, it creates new issues. According to Lucarelli (2014, p. 211-213): "The imposition of a one size fits all monetary policy by the ECB has only exacerbated asymmetries between the low-inflation and high-inflation countries." We argue that due to the political motivations, there is a lack of emphasis on real competitive advantages ${ }^{12}$ when compared to the past. The current expansionary monetary policy of the ECB is like trying to start a broken engine by kicking it. Therefore, solving the indebtedness using mainly money financing in the EMU is not a good solution. Looking at it from another perspective, the current situation is made by political decisions which seem to be trapped in a false ideology or a sunk cost fallacy. The idea of "buying time" before some significant changes are made is not very convincing either as there are no guarantees and it paradoxically helps with sustaining the current status quo. Baltatescu (2013) argues that even if a fiscal union is set up, there are no reasons to believe that the debt problem of Euro area will be solved, provided that the socialisation of risks and losses across eurozone remains possible. A

\footnotetext{
11 It is morally unjustifiable.

${ }^{12}$ We mean competitive advantages created by using other ways than by those affecting the exchange rates.
} 
slightly better solution is to cut the debt using own currency inflation (which would mean leaving the eurozone for some countries), however, as mentioned, the option is inefficient when considering its other effects, and dangerous.

\subsection{Fiscal consolidation}

\subsubsection{One-shot solution - sale of assets}

Table no. 5 illustrates total government financial assets of the selected countries in 2015, or 2016. Even under the assumption of selling all these assets, only France could make its indebtedness ratio to GDP below $60 \%$. However, it is almost certain that some assets are of a low performance or illiquid, thus could not be easily sold. Moreover, selling performing assets would mean, from a long-term perspective, higher debt inertia. Finally, a sale of certain short-term instruments could disrupt budget management of a country.

Table no. 5 - Total government financial assets (\% of GDP, 2015-2016)

\begin{tabular}{l|ccccc} 
& Spain & France & Greece & Italy & Portugal \\
\hline Total financial assets & 33.22 & 44.66 & 40.07 & 26.96 & 43.47
\end{tabular}

Source: OECD, own processing. Notes: The data are reported within the SNA 2008 framework.

The values for France and Italy are from 2015, the rest is from 2016.

There is a lack of data on non-financial assets. Nevertheless, in case of France, we can see that these assets are usually made mostly of buildings and natural resources, ${ }^{13}$ not fit to sell under standard circumstances. When a state is pushed into selling its assets, there is probably an opportunistic behaviour of subjects that are willing to buy them. It has nothing to do with an optimal strategy, ${ }^{14}$ and as a form of punishment, it will hurt the economy further.

\footnotetext{
${ }^{13}$ According to the OECD database.

14 There may exist some exceptions, however, it should not be significant.
} 


\subsubsection{Structural solutions - revenues and expenditures}

A scope of reduction of indebtedness depends on how effective a fiscal consolidation is. In other words, which tools of consolidation are used and how strictly and how fast they are implemented. From the theoretical perspective, even short-term increase in government debt may help to boost growth and subsequently lower a relative indebtedness. However, in reality, an assumption of making credible investments is usually not fulfilled.

While the opinions on fiscal consolidation in a relevant literature are mixed, there are no other tools of reducing indebtedness left beside GDP growth and default. The EU experienced some events of sizeable reductions in the debt ratio (ECB, 2010, p. 83). For instance, 50 percentage points in Belgium (from 1994 to 2007), and up to more than 69 percentage points in Ireland (from 1994 to 2006).

Cafiso and Cellini (2014) claim that fiscal consolidations are ineffective in reducing relative indebtedness. Jeong (2017) reached the same conclusion. On the other hand, it can be theoretically argued that fiscal consolidations can help countries escape from a bad or unsustainable equilibrium (Padoan, Sila, \& van den Noord, 2012). Such programs may boost market confidence and lower risk premia over a longer period of time. Fiscal consolidation may initially depress growth, but arguably not to an extent where this would push a country into a bad equilibrium or prevent it from escaping from it (ibid., p. 24). According to Cottarelli, Gerson, and Senhadji (2014), history shows several episodes of fiscal adjustments that were characterised by medium-term sustainable growth. A growth is needed to ensure that a country is not losing its international competitiveness and it further supports reducing of an indebtedness. Historical experience demonstrates that drastic consolidation measures will face massive political resistance and a sharp increase in unemployment (Baumgarten \&Klodt, 2010, p. 375). Agradual adjustment would probably be the most suitable pace of consolidation. 
There are two possible ways of balancing a budget - either by increasing revenues or cutting expenditures. Theoretically, raising taxes (increasing revenues) is problematic as it dampens people's motivations to work, it raises costs, reduces country's competitiveness. Eventually, it constricts GDP growth and lowers potential GDP. Attinasi and Metelli (2016) argue that when fiscal consolidation is based on an increase in government revenues, the initial increase in the debt ratio is stronger and, eventually, the debt ratio reverts to its preshock level, resulting in a so-called self-defeating austerity. Even critics of fiscal consolidations, Cafiso and Cellini (2014) recommend that such measures should be based on savings and increasing revenues because fiscal consolidations that are made by an increase in taxation are more likely to have adverse medium-term effects. According to the Eurostat database, France in 2015 was characterised by having the highest tax wedge when compared to other EU countries. Arguably, the country has reached a tipping point of the Laffer's curve. In addition, Italy and Greece also ranked among the first 10 states. Portugal and Spain are performing relatively better, yet, the differences from EU19 or EU28 are not significant. To conclude, effective fiscal consolidations should be gradual, credible, and should focus on cutting expenditures.

\subsubsection{Structural solutions - Administrative measures}

Forms of administrative measures - various fiscal rules, seem from theoretical perspective ineffective when used as the main tool of preventing debt accumulation. Such measures are basically tools of social or central planning. The situation is worse when considering that these rules are also imposed on sovereign countries, that is why these rules on a supra-national level are mostly recommendations. It is obvious that main impulses must come from within the economy, not as a purely external factor. Of course, politicians agreed to follow such measures, however, their pledge in the case of the EU was rather populistic. Another piece of evidence may provide general public as the majority of people do not know that such measures even exist. We 
believe that if some alterations of political incentives like these were working, there would need to exist other, more strict pressures such as voter demand. Therefore, the effectiveness highly depends on an individual state and its position in time. Furthermore, when such rules are applied, these countries are usually facing problems already, and they needed to implement some other measures prior to the implementation of fiscal rules. Therefore, it is highly problematic to empirically measure the effect of imposed fiscal rules (there is a form of endogeneity). Heinemann, Moessinger, and Yeter (2017) used a metaregression-analysis concerning the budgetary impact of numerical fiscal rules based on 30 studies published in the last decade. They found positive effects of these rules, however, they added that due to the potential endogeneity there may exist a bias. In addition, they found a presence of publication bias. There is an urgent need to develop other strategies such as independent fiscal boards or the role of disciplining incentives from bond markets (ibid., p. 27). The latter is, however, impossible in the current state of quantitative easing as mentioned in the previous chapter. To sum it up, it is possible that administrative measures are rather cosmetic, and they do not have the ability to make a fundamental difference.

\subsection{Structural reforms promoting economic growth}

Structural reforms of the economies that would promote economic growth is the last possible option, a possibly the most effective one, provided that government does not want to default. The option helps in three ways. First, government budget may be financed by obtaining more revenues due to a booming economy. Second, if an absolute value of accumulated debt does not change, higher GDP means a smaller debt to GDP ratio. Third, harsh austerity measures may eventually lead to social unrest (Sarcinelli, 2012, p. 231), GDP growth is able to significantly reduce such possibility.

Table no. 6 shows historical averages of real GDP growth of the countries. Data from the last 21 years indicate that GDP growth cannot 
serve as the main tool of reducing relative indebtedness when comparing the data with the table no. 4 (real interest rates were higher most of the time $)^{15}$. Average growths in the post-crisis period are also weaker than their 21 year averages. Of course, historical values cannot serve as a straightforward evidence, but they provide a good estimate.

Table no. 6 - Real GDP growth rates of the selected countries (averages, in \%)

\begin{tabular}{|c|c|c|c|c|c|c|}
\hline Country & $\begin{array}{c}\text { Full } \\
\text { period } \\
(1996- \\
2016)\end{array}$ & $\begin{array}{l}\text { Actual } \\
\text { year } \\
(2016)\end{array}$ & $\begin{array}{c}\text { First } \\
\text { decade } \\
\text { (1996- } \\
\text { 2005) }\end{array}$ & $\begin{array}{c}\text { Second } \\
\text { decade } \\
(2006- \\
2015)\end{array}$ & $\begin{array}{l}\text { Crisis } \\
\text { period } \\
(2007- \\
2010)\end{array}$ & $\begin{array}{l}\text { After- } \\
\text { crisis } \\
\text { period } \\
(2011- \\
2016)\end{array}$ \\
\hline Spain & 2.12 & 3.24 & 3.75 & 0.41 & 0.30 & 0.33 \\
\hline France & 1.55 & 1.21 & 2.28 & 0.86 & 0.37 & 0.99 \\
\hline Greece & 0.72 & 0.01 & 3.77 & -2.17 & -1.77 & -3.33 \\
\hline Italy & 0.51 & 0.88 & 1.47 & -0.47 & -0.89 & -0.38 \\
\hline Portugal & 1.16 & 1.43 & 2.46 & -0.16 & 0.38 & -0.53 \\
\hline
\end{tabular}

Source: Eurostat, own processing.

Possibly a more precise information is obtained from the decomposition of debt dynamics, i.e. effects of GDP growth, which is presented in table no. 7. For the given period, not a single examined country achieved that GDP growth was the main factor of change in indebtedness for at least $40 \%$ of the time. In addition, these episodes were usually occurring in the periods of prosperity and high growth, not in situations when a country was having serious problems. As a result,

\footnotetext{
${ }^{15}$ A primary balance, as it can be seen in the appendix, has only a minor effect.
} 
we do not suggest an approach to GDP growth which is solely demand-driven.

Table no. 7 - GDP growth as the dominant factor of a change in indebtedness (1996-2016)

\begin{tabular}{c|ccccc} 
& Spain & France & Greece & Italy & Portugal \\
\hline No. of episodes in 21 years & 7 & 6 & 5 & 8 & 6
\end{tabular}

Source: Eurostat, own calculations and processing.

Note: The values were calculated on the basis of the equation no. 6 .

A crucial question, when solving debt issues, is how the growth would be created, and whether it is sustainable or not. Do the current monetary and fiscal policies in the EMU create such growth? Obviously not, although policy makers often use the argument of positive effects of economic growth. Sustainable and a strong economic development can be created by boosting competitive advantages. First, a change of monetary policy is needed to stop giving governments incentives to accumulate debt by reducing sovereign bond interest rates ${ }^{16}$. Second, it would mean change in the eurozone's design and structure - exit of some countries, annulment of socialisation of risks and losses in the EMU (as stated by Baltatescu, 2013) or even in the whole European Union. The problem is that the European Union is trying to deal with many issues, while promoting unstable and non-functional deeper political integration, at least in case of some countries. In addition, countries need to cut the size of its public sector, a snowball effect has taken place for decades ${ }^{17}$. There is also a need of reducing bureaucratic and tax burden for the private sector as well as making

\footnotetext{
16 The problem is complex, reducing interest rates may serve as a positive factor, however, as we have stated in the relevant chapter, the current monetary policy in the EMU has a lot of negative effects. The policy advocates are using a false argumentation.

${ }^{17}$ We take this as a fact, see OECD data for example.
} 
effective investments in education ${ }^{18}$ and research and development. To conclude, a return to market principles in many cases is needed. If there is no major change, we should be expecting years of weak economic growth while increasing debt burden at the same time. In such case, the Southern countries will be in the worst position.

\subsection{Government default}

When a country is not capable of fully repaying its debt, a government default occurs. Moreover, cases of a sovereign default are, possibly, not completely similar. Especially defaults in a monetary union should be treated carefully. The consequences of a sovereign default are quite straightforward. Lender entity loses its resources, while the debtor country (and its citizens) face possible consequences in terms of reputations costs, possible sanctions, or economic, political, and social crises. Nevertheless, implications of sovereign indebtedness are different from a private indebtedness (Borensztein \& Panizza, 2008, p. $3)$. In the former case, the creditors are not as strong as in the case of private debts. Also, the legal rights of getting the money back are, in fact, limited because of the sovereignty of the debtor country (ibid.).

Table no. 8 illustrates a history of nearly 200 years in terms of sovereign defaults ${ }^{19}$. From this perspective, Greece, Spain, and Portugal showed most of the events. Moreover, Greece spent more than half of the selected period in default, with the longest episode lasting for 33 years (1932-1964). Unfortunately, these events are not so rare. In addition, these countries usually defaulted on basis of a foreign debt. The current situation is no exception.

\footnotetext{
${ }^{18}$ A proper education can possibly solve many issues, including those resulting from a political process.

19 The shorter time period was used in the case of some countries due to data availability issues. We needed to ensure that the periods are the same, so they are comparable.
} 
Table no. 8 - Length of sovereign defaults, both domestic and external debt, (1820-2016)

\begin{tabular}{c|ccccc} 
Country & Spain & France & Greece & Italy & Portugal \\
\hline No. of episodes & 6 & 0 & 7 & 1 & 5 \\
Total length & 47 years & 0 years & 119 years & 7 years & 24 years
\end{tabular}

Source: Reinhart (2010) and the CRAG Database - June 2017, own processing.

The literature offers some insights into historical default costs. It agrees that a default event means high costs for the debtor state, although there is some evidence that the long-lasting effects are not always present ${ }^{20}$. Baer, Margot, and Montes-Rojas (2011) analysed the default of Argentina in 2001. They concluded that it was accompanied by catastrophic economic, political and social crisis which reduced its significance and made multilateral institutions to be more sympathetic. Arguably, the Southern countries of the EU are in a similar situation. Borensztein and Panizza (2008, p. 3) list four types of costs that may result from an international sovereign default: reputational costs, international trade exclusion costs, costs to the domestic economy through the financial system, and political costs to the authorities. They found that these costs are generally significant (but short-lived), especially political costs. Gros and Mayer (2011, p. 30) mention possible problems connected to a "debt restructuring" in case of Greece: it may be too costly, it is no substitute for the comprehensive economic adjustment required in the troubled countries, these states would lose market access ${ }^{21}$ for a very long time, a debt restructuring will create moral hazard, it would lead to a broader crisis. The authors explain why the issues are problematic and cannot be easily accepted. However, another series of significant defaults in the EMU would mean

\footnotetext{
${ }^{20}$ We are not mentioning the crisis in the EMU/EU, because we assume, that it has not ended yet.

${ }^{21}$ Especially capital market access.
} 
making the EMU (or the whole EU) even less economic effective than it is nowadays while accounting for many structural problems. Furthermore, Gros and Mayer (ibid.) are correct when stating a default is needed in extreme cases to set a country on the "right" track again. Also, a creation of moral hazard is not very likely to happen when a socialization of risks in the EMU is in place, however, those policies are not fit for a sustainable economic progress. The authors add that lenders should be punished for lending these countries. Some authors (for example Skaperdas, 2015, p. 758-759) point out that interests of government officials and the interests of the country and its people are different, therefore, people should not be hurt. The institute of democracy is not perfect; however, the argument is invalid because there would be a lack of responsibility for elections which would further impede the efficiency of the political process. The initial argument seems convincing even though most of these lenders are people of the EU. According to Skaperdas (2015, p. 758): "If the lender has not been careful in choosing his borrowers, then it is both economically efficient and fair that he loses. From an economic viewpoint, it is clear that the possibility of bankruptcy has been a usual source of improvement, renewal, and vitality in the economies that allow it."

While a default is an ultimate solution, it is obvious that it should be an option of last resort. The question is whether the situation in the EMU is in such desperate situation. Skaperdas $(2015$, p. 768$)$ claims that an event of default may not be necessarily as disastrous as it is presented. Without the euro, it is difficult to imagine how a crisis of such depth would have occurred (ibid.). Furthermore, as we have shown in the paper, if nothing significant happens, ${ }^{22}$ the Southern countries (excluding Italy) are caught in a debt trap which could lead to a dangerous spiral of raising debt while experiencing economic stagnation. If the current status quo is being preserved, it seems fit for these countries to default. It would help in shaping voters' demand, thus, helping the political process (the subjects involved would face

${ }^{22}$ Such as reconsidering the design of the eurozone or implementing pro-growth reforms. 
immediate consequences). And subsequently, it would accelerate reforming of the EU's and the Eurozone's structural weaknesses as well as discarding unreasonable policies. In other words, defaults would accelerate functioning of correction mechanisms (or help with their creation) in the EMU and the EU, if there is no political will to do so.

Nevertheless, a special cause of a de-facto bankruptcy in the case of Greece needs to be addressed. From both empirical and theoretical perspective, such significant event as government default needs to be executed properly. Half-done policies, especially when facing a severe crisis, are not usually successful. In other words, bailed-out bankruptcy which can serve as a preserver of a current status-quo does not bear the desired effects.

\section{Conclusions}

According to the literature, there is no doubt about the negative effects of high debt to GDP ratio. It is believed that it takes place between $85 \%$ and $100 \%$ of gross debt to GDP. We have examined five Southern countries of the European Union - Spain, France, Greece, Italy, and Portugal. All of them exhibit the ratio close to $100 \%$ or even higher. Therefore, we conclude that their economic growth is negatively affected. We claim that there is no need to completely get rid of the debt, however, a sufficient level seems to be $60 \%$ as recommended by the Maastricht criterion.

We have shown that all the countries, except Italy, are caught in a debt trap, under the assumption that the values of influential variables are close to their historical averages from 1996 to 2016. On top of that, they do not run a sustainable fiscal policy judging by the differences between actual primary balances and stabilising primary balances. There is an evidence that Portugal and Greece are in the worst relative position. Surprisingly, some of Portugal's parameters are even worse than in the case of Greece. 
We identified four main possibilities of dealing with the debts: debt monetization, fiscal consolidation, structural reforms (or boosting GDP growth), and sovereign default.

Debt monetization as implemented by the ECB has many secondary effects, such as making imbalances in the Target2 system, thus raising the probability of another bailout taking place. Moreover, the socialisation of risks and losses probably strengthens moral hazard in the EMU/EU. Possible inflationary pressures could create other instabilities, uncertainty, and there is no particular reason why debtors should benefit at the expense of creditors. Furthermore, some effects are hidden. Many states' housing markets are booming, and both prices and yields of government bonds are affected. The crucial aspect is that governments issuing financial instruments experience no relevant feedback (or punishment) which would arise from their expansionary policies. The current strategy of the ECB undoubtedly helped in the short-term, most notably during the crisis. However, it is a fatal mistake to continue the trend because it will make the situation even worse. The current monetary policy of the ECB is like trying to start a broken engine by kicking it. Looking at it from another perspective, the current situation is made by political decisions which seem to be trapped in a false ideology or a sunk cost fallacy. The idea of "buying time" before some significant changes are made is not very convincing either as there are no guarantees and it paradoxically helps with sustaining the current status quo. All in all, debt monetisation is a poor solution to the debt problem.

The second possibility is a fiscal consolidation. We concluded that oneshot solutions are rather inappropriate. Even if the states sold all their financial assets, only France could make its indebtedness ratio to GDP below $60 \%$. Furthermore, selling assets would possibly make the problem even worse because the country would lose some revenues in the long-term. According to the literature, fiscal consolidation should be gradual, credible, and should focus on cutting expenditures rather than increasing revenues by raising tax rates. After all, there is not much 
space for raising taxes. While the opinions on the effectiveness of fiscal consolidation are mixed, it can be argued that, if done correctly, it should help in the long-term by boosting market confidence and lowering risk premia beside the decrease in relative indebtedness. Various forms of administrative measures seem ineffective when used as the main tool of preventing debt accumulation. Such measures are basically tools of social or central planning.

Structural reforms of the economies that would promote economic growth is probably the most effective option, if government does not want to default. However, the countries experienced low GDP growths in the last 21 years. Moreover, not a single examined country achieved that GDP growth was the main factor of change in indebtedness for at least $40 \%$ of the time in the given period. Also, sustainable and a strong economic development can be created by boosting competitive advantages, not by the current monetary and fiscal policies in the EMU/EU. Therefore, the reforms cannot be solely demand-driven. We argue that due to the political motivations, there is a lack of emphasis on real competitive advantages when compared to the past. A return to market principles in many cases is needed in order to support the reform efforts.

A sovereign default should be an option of last resort. However, the default is not a rare event. For instance, Greece spent more than half of the selected period (1820-2016) in default. Finally, we conclude that if the current status quo is being preserved, it seems fit for these countries to default. It would help functioning of the political process (the subjects involved would face immediate consequences). And subsequently, it would accelerate reforming of the EU's and the Eurozone's structural weaknesses as well as discarding unreasonable policies. In other words, defaults could speed up the functioning of correction mechanisms (or help with their creation) in the EMU and the $\mathrm{EU}$, if there is no political will to do so. However, the action needs to be executed properly. A sovereign default which is half-way done, as in 
the case of Greece, and is used to preserve the current status-quo is insufficient and ineffective. 


\section{Appendices}

A. Historical averages of gross government debt to GDP ratios (in \%)

\begin{tabular}{|c|c|c|c|c|c|c|}
\hline Country & $\begin{array}{c}\text { Full } \\
\text { period } \\
(1996- \\
2016)\end{array}$ & $\begin{array}{c}\text { Actual } \\
\text { year } \\
(2016)\end{array}$ & $\begin{array}{c}\text { First } \\
\text { decade } \\
(1996- \\
2005)\end{array}$ & $\begin{array}{c}\text { Second } \\
\text { decade } \\
(2006- \\
2015)\end{array}$ & $\begin{array}{l}\text { Crisis } \\
\text { period } \\
(2007- \\
2010)\end{array}$ & $\begin{array}{l}\text { After- } \\
\text { crisis } \\
\text { period } \\
(2011- \\
2016)\end{array}$ \\
\hline Spain & 63.59 & 99.26 & 55.90 & 67.72 & 46.92 & 91.65 \\
\hline France & 72.77 & 96.65 & 61.57 & 81.57 & 73.24 & 92.51 \\
\hline Greece & 126.95 & 181.33 & 102.57 & 145.90 & 121.38 & 175.21 \\
\hline Italy & 112.51 & 132.60 & 106.48 & 116.53 & 107.52 & 127.55 \\
\hline Portugal & 79.59 & 130.30 & 53.32 & 100.78 & 79.97 & 126.09 \\
\hline
\end{tabular}

B. Historical averages of actual primary balances (\% of GDP)

\begin{tabular}{|c|c|c|c|c|c|c|}
\hline Country & $\begin{array}{c}\text { Full } \\
\text { period } \\
\text { (1996- } \\
2016)\end{array}$ & $\begin{array}{c}\text { Actual } \\
\text { year } \\
(2016)\end{array}$ & $\begin{array}{c}\text { First } \\
\text { decade } \\
(1996- \\
2005)\end{array}$ & $\begin{array}{c}\text { Second } \\
\text { decade } \\
(2006- \\
2015)\end{array}$ & $\begin{array}{c}\text { Crisis } \\
\text { period } \\
(2007- \\
2010)\end{array}$ & $\begin{array}{c}\text { After- } \\
\text { crisis } \\
\text { period } \\
(2011- \\
2016)\end{array}$ \\
\hline Spain & -1.7 & 3.9 & 0.2 & -4.2 & -5.8 & -2.3 \\
\hline France & -0.9 & -1.7 & 1.7 & -3.5 & -4.1 & -4.1 \\
\hline Greece & -0.9 & -1.5 & 0.2 & -1.9 & -2.4 & -1.9 \\
\hline Italy & 2.3 & 1.6 & 3.3 & 1.4 & 1.2 & 1.6 \\
\hline
\end{tabular}



Portugal
2.2
$-1.3$
$-2.3$
$-4.0$
$-0.6$
C. Historical averages of stabilizing primary balances (\% of GDP)

\begin{tabular}{|c|c|c|c|c|c|c|}
\hline Country & $\begin{array}{c}\text { Full } \\
\text { period } \\
(1996- \\
2016)\end{array}$ & $\begin{array}{c}\text { Actual } \\
\text { year } \\
(2016)\end{array}$ & $\begin{array}{c}\text { First } \\
\text { decade } \\
\text { (1996- } \\
\text { 2005) }\end{array}$ & $\begin{array}{c}\text { Second } \\
\text { decade } \\
(2006- \\
2015)\end{array}$ & $\begin{array}{l}\text { Crisis } \\
\text { period } \\
(2007- \\
2010)\end{array}$ & $\begin{array}{c}\text { After- } \\
\text { crisis } \\
\text { period } \\
(2011- \\
2016)\end{array}$ \\
\hline Spain & 1.37 & -2.30 & -2.79 & 6.74 & 5.72 & 8.94 \\
\hline France & 1.36 & -0.76 & 2.11 & 0.44 & 2.85 & -1.53 \\
\hline Greece & 3.60 & 3.21 & -1.39 & 10.65 & 12.29 & 12.19 \\
\hline Italy & 1.45 & 1.25 & -0.37 & 3.48 & 4.67 & 2.81 \\
\hline Portugal & 3.98 & 3.78 & 1.51 & 7.47 & 6.84 & 7.85 \\
\hline
\end{tabular}

Source: Eurostat, own calculations and processing.

Note: The calculations of stabilizing primary balances were based on the equation no.

5. 


\section{Decomposition of factors influencing debt dynamics of the} selected countries(1996-2016, in \%)

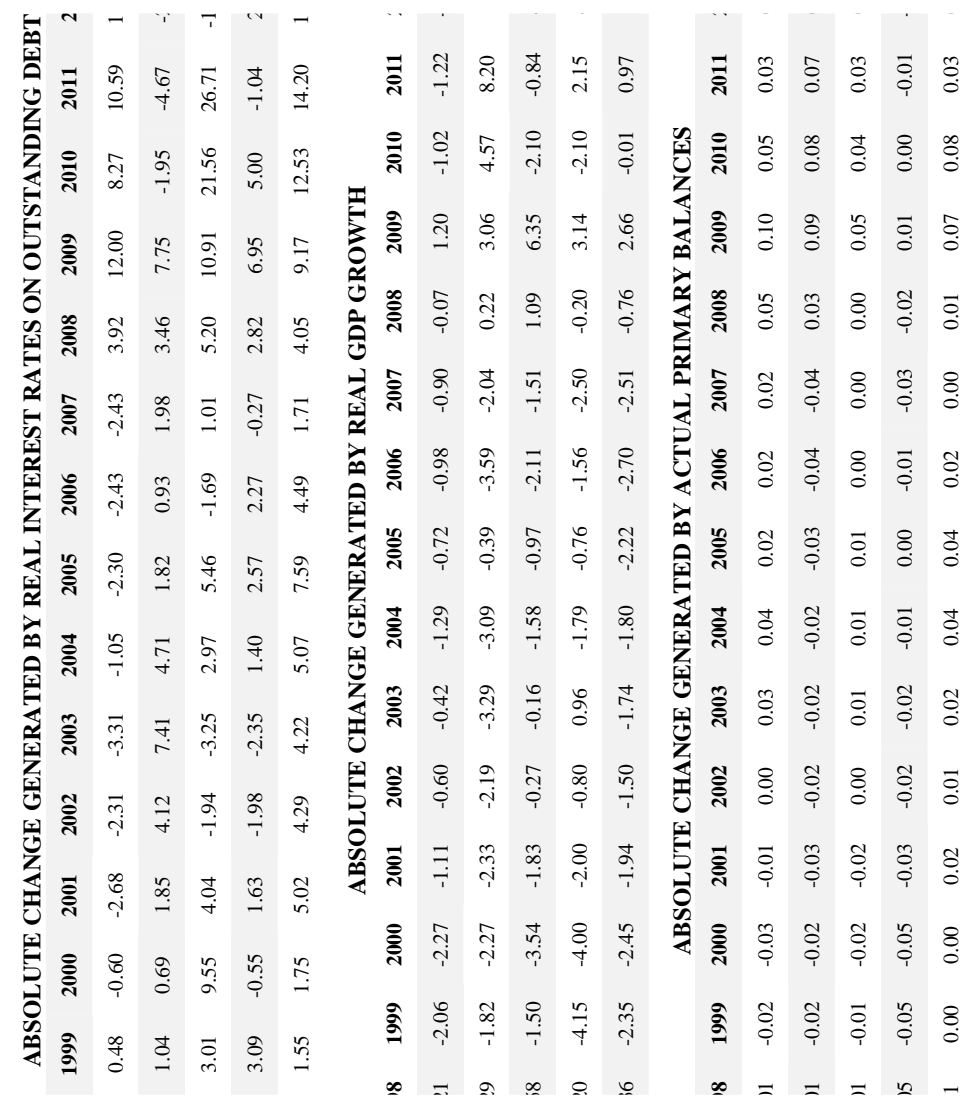

Source: Eurostat, own calculations and processing.

Note: The corresponding values were calculated on the basis of the equation no. 6 


\section{References}

Attinasi, M. G. \& Metelli, L. (2016). Is fiscal consolidation self-defeating? A panel-VAR analysis for the euro area countries. European Central Bank Working Paper No. 1883.

Baumgarten, M., Klodt, H. (2010). Greece and Beyond: The Debt Mechanics of the Euro. Aussenwirtschaft, 65(4), 365-377.

Baer, W., Margot, D. \& Montes-Rojas, G. (2011). Argentina's default and the lack of dire consequences. Economía Aplicada, 15(1), 131-146.

Baltatescu, I. (2013). Eurozone public debt problem: an analysis from the perspective of the institutions and policies. Global Economic Observer, 1(1), 83-92.

Borensztein, E., Panizza, U. (2008). The Costs of Sovereign Default. IMF Working Paper No. 08/238. https://doi.org/10.5089/9781451870961.001

Brennan, G. (2012). The political economy of public debt. Constitutional Political Economy, 23(3), 182-198. https://doi.org/10.1007/s10602-012-9124-5

Cafiso, G. \& Cellini, R. (2014). Fiscal consolidations and public debt in Europe. International Tax and Public Finance, 21(4), 614-644. https://doi.org/10.1007/s10797-014-9319-y

Cecchetti, S. G., Mohanty, M., \& Zampolli, F. (2010). The future of public debt: prospects and implications. BIS Working Papers No. 300. https://doi.org/10.2139/ssrn.1599421

Cottarelli, C., Gerson, P. R., \& Senhadji, A. (2014). Post-crisis fiscal policy. $\begin{array}{llll}\text { Cambridge } \quad \text { (Mass.): } & \text { The PIT }\end{array}$ https://doi.org/10.7551/mitpress/9780262027182.001.0001

De Nederlandsche Bank. (2016). Target2 imbalances reflect QE and persistent fragmentation within the euro area. DNBulletin (June 2016).

European Central Bank. (2010). Economic and Monetary Developments: Fiscal Developments. ECB Monthly Bulletin (June 2010). 
Escolano, J. (2010). A Practical Guide to Public Debt Dynamics, Fiscal Sustainability, and Cyclical Adjustment of Budgetary Aggregates. International Monetary Fund - Fiscal Affairs Departments. https://doi.org/10.5089/9781462396955.005

Égert, B. (2015). The $90 \%$ public debt threshold: the rise and fall of a stylized fact. Applied $\quad$ Economics, 37(34-35), 3756-3770. https://doi.org/10.1080/00036846.2015.1021463

Gál, Z., \& Baboš, P. (2014). Avoiding the high debt-low growth trap: lessons for the new member states. Verslo Sistemos ir Ekonomika, 4(2), 154-167. https://doi.org/10.13165/VSE-14-4-2-04

Gros, D. (2012). On the Stability of Public Debt in a Monetary Union. Journal Of Common Market Studies, 5036-48. https://doi.org/10.1111/j.14685965.2012.02273.x

Gros, D., \& Mayer, T. (2011). To default or not to default? CESifo Forum, 12(2), 2933.

Heinemann, F., Moessinger, M. D., \& Yeter, M. (2017). Do fiscal rules constrain fiscal policy? A meta-regression-analysis. European Journal of Political Economy, (in press).

Herndon, T., Ash, M., \& Pollin, R. (2013). Does high public debt consistently stifle economic growth? A critique of Reinhart and Rogoff. Cambridge Journal of Economics, 38(2), 257-279. https://doi.org/10.1093/cje/bet075

Hishow, O. N. (2011). Germany's debt brake: Pulling the EU out of its debt trap? Intereconomics, 46(6), 327-331. https://doi.org/10.1007/s10272-011-0396-1

Jeong, K. J. (2017). Effects of Fiscal Consolidation in 18 OECD Countries. Seoul Journal of Economics, 30(1 2017), 51-91.

Lucarelli, B. (2014). German neomercantilism and the European sovereign debt crisis. Journal of Post Keynesian Economics, 34(2), 205-224. https://doi.org/10.2753/PKE0160-3477340202

Padoan, P. C., Sila, U., \& van den Noord, P. (2012). Avoiding Debt Traps: financial backstops and structural reforms. OECD Economic Department Working Papers 976. 
Reinhart, C. M. (2010). This Time is Different Chartbook: Country Histories on Debt, Default, and Financial Crises. NBER Working Paper No. 15815. https://doi.org/10.3386/w15815

Reinhart, C. M., \& Rogoff, K. S. (2010). Growth in a Time of Debt. American Economic Review, 100(2), 573-78. https://doi.org/10.1257/aer.100.2.573

Sarcinelli, M. (2012). Euro crisis or public debt crisis? With a remedy for the latter. PSL Quarterly Review, 65(262), 215-236.

Skaperdas, S. (2015). Myths and Self-Deceptions about the Greek Debt Crisis. Revue d'Économie Politique, 1(6), 755-785. https://doi.org/10.3917/redp.256.0755

Stanley, T. D. (1998). New Wine in Old Bottles: A Meta-Analysis of Ricardian Equivalence. Southern Economic Journal, 64(3), 713-727. https://doi.org/10.2307/1060788

Strecha, M. (2015). Public debt structure as an origin of economic instability. Actual Problems in Economics, 1(164), 328-338.

Woo, J., \& Kumar, M. S. (2015). Public Debt and Growth. Economica, 82(328), 705739. https://doi.org/10.1111/ecca.12138 